\title{
WHY THE NEED FOR CONSUMER PROTECTION LEGISLATION? A LOOK AT SOME OF THE REASONS BEHIND THE PROMULGATION OF THE NATIONAL CREDIT ACT AND THE CONSUMER PROTECTION ACT
}

\author{
Tanya Woker \\ BA LLB LLM PhD \\ Professor, University of Kwazulu-Natal, Durban \\ Chairperson of the Consumer Affairs Committee \\ (Department of Trade and Industry)
}

\section{SUMMARY}

Two statutes focusing on consumer protection have been introduced recently: the Consumer Protection Act due to come into effect in October 2010 and the National Credit Act. There are many who criticize this legislation, arguing that this will overburden the economy and will lead to significant costs for business. In this article I examine some of the reasons why the Department of Trade and Industry deemed it necessary to introduce consumer protection legislation. I conclude by arguing that despite the increased costs for business, the legislation is necessary in order to prevent the exploitation of consumers by business that presently exists in South Africa. I do not, however, seek to answer the question whether this legislation will achieve its lofty aims. This, only time will tell. However, many acknowledge that the introduction of the National Credit Act shielded South Africa from some of the worst excesses of the global recession of $2008 / 2009$. It is hoped that the Consumer Protection Act will likewise change the way many in South Africa do business.

\section{$1 \quad$ INTRODUCTION}

The Consumer Protection Act ${ }^{1}$ is due to come into effect in October 2010. This is a comprehensive statute which introduces substantial consumer protection measures. This legislation follows the introduction of the National Credit $\mathrm{Act}^{2}$ which also promotes extensive consumer protection and which has been in full effect since 1 June 2007. Although both these statutes are to be welcomed for the consumer protection measures they introduce, they also impose heavy compliance and other burdens on those who supply products and services. This begs the question: Is the introduction of

Act 68 of 2008 .

Act 34 of 2005 . 
consumer protection legislation really necessary in South Africa? This article seeks to examine some of the reasons why the Department of Trade and Industry (DTI) deemed it necessary to introduce this legislation because there are those who argue that the economy will only function effectively in circumstances where state intervention is kept to an absolute minimum. ${ }^{3}$ True protection for consumers and other entrepreneurs is, therefore, through the strengths of the market and the development of competition. ${ }^{4}$ The South African government was criticised in $\mathbf{2 0 0 0}$ for producing more legislation in its first five years than any comparable parliament in the Western World. ${ }^{5}$ Before the global financial crisis which led to the recession of 2008/2009 South Africa's financial regulatory supervisory and prudential framework was under severe pressure with calls for its amendment and even abolition. ${ }^{6}$ Those who support non-government intervention in the economy argue that when consumers have a problem they can resort to existing protection measures or the common law where there are ample provisions to protect their rights. ${ }^{7}$

It must be accepted that in a free-market economy the ideal is for there to be as little state intervention as possible and there is always the danger that consumer protection measures will be over-protective and will interfere with the consumer's right to free choice. It is important therefore to assess why the system which regulated the market place was regarded as flawed in order to establish whether consumer protection legislation was in fact called for.

\section{CONSUMER LAW IN SOUTH AFRICA}

Until recently it was probably incorrect to use the term "consumer law" in South Africa because there was no comprehensive and systematic body of law which was designed specifically to deal with consumer issues. Nevertheless consumer protection measures have existed for many years in certain industry specific legislation which deal with matters such as finance charges, ${ }^{8}$ weights and measures, ${ }^{9}$ food, ${ }^{10}$ trade descriptions on goods ${ }^{11}$ and

3 See Cranston Consumers and the Law (1978) 18-26, Baldwin and Cave Understanding Regulation (1999) 210-211; and Pengilley "Regulatory Power and Free Trade: The Rules of Engagement in the Era of De-Regulation" 2002 QUT Law \& Justice Journal 1.

4 Baldwin and Cave 210-211; and ITOSAI Working Group on the Audit of Privatisation "Guidelines on Best Practice for the Audit of Economic Regulation" 4 http://www.nao.org.uk/intosai/wgap/ecregguidelines.htm (accessed 2005-02-08).

5 Law Review Project "Opinion concerning the Consumer Affairs (Unfair Business Practices) Act 71 of 1988 of General Interest to National and Provincial Government" 17 March 2000. The Law Review Project is an independent legal resource organisation that works closely with the Free Market Foundation. The Free Market Foundation is highly critical of overregulation and advocates the removal of excessive restrictions on the economy. See Louw "Consumer Protection Bill" http//www.freemarketfoundation.com (accessed 2007-02-18).

6 Financial Services Board "Regulatory Overhaul: Throw the Bath Water out but Keep the Baby" 2009 Fourth Quarter FSB Bulletin 3. Today, this stringent regulatory system and the National Credit Act have been credited with saving South Africa from the worst effects of the global crisis.

7 Cranston 18-26.

8 The National Credit Act 34 of 2005 replaced the Usury Act 73 of 1968 and the Credit Agreements Act 75 of 1980 . 
false and misleading advertising. ${ }^{12}$ General consumer protection measures are found in the national and provincial Consumer Affairs (Unfair Business Practices) legislation and a number of other statutes that may be administered by the various provinces or by the national government. There are also a number of different regulators which are responsible for enforcing standards and product safety and for ensuring that businesses do not contravene the various statutes. These regulators include the DTI, the South African Bureau of Standards (SABS) and the Departments of Agriculture, Health and Environmental Affairs. Unfortunately there has always been a lack of co-ordination between the various regulators, and these disjointed pieces of legislation are often unknown to consumers and suppliers alike. Further they tend to provide little protection for consumers or have been applied in an inconsistent manner. ${ }^{13}$

\section{THE CONSUMER AFFAIRS (UNFAIR BUSINESS PRACTICES) ACT $^{14}$}

The purpose of this Act is to provide for the prohibition or control of unfair business practices but it does not contain a list of practices that may be considered unfair. This is an enabling Act rather than a prescriptive one and the Act itself does not prohibit anything. The Act authorizes the Consumer Affairs Committee (known as CAFCOM) to investigate business practices and to report to the Minister. This Committee is a statutory body in the Department of Trade and Industry. Its members are not in the full-time employment of the state but are appointed on the grounds of having special knowledge or experience of consumer advocacy, economics, industry, commerce or law. The Committee may investigate any business practice and if a particular business practice is found to be unfair it makes recommendations to the Minister. If the Minister accepts these recommendations, he publishes a notice in the Government Gazette declaring the business practice to be unfair and directs that parties and/or businesses to refrain from applying them. The order may mean that certain practices must be amended and the business may continue as before or it

9 Measuring Units and National Measuring Standards Act 76 of 1973 which has now been replaced by the Measurement Units and Measurement Standards Act 18 of 2006.

10 Foodstuffs, Cosmetics and Disinfectants Act 54 of 1972 amended by the Foodstuffs, Cosmetics and Disinfectants Amendment Act of 2007.

11 Merchandise Marks Act 17 of 1941 amended by the Merchandise Marks Amendment Act of 2002.

12 There are many statutes that regulate and, in some cases, ban certain types of advertisements. In South Africa tobacco products cannot be advertised (Tobacco Products Control Act 83 of 1993). There are also calls to ban the advertising of alcohol and control the advertising of fast foods.

13 In most instances, a contravention of a particular statute is a criminal offence and there are penalties attached. However, the matter must be prosecuted by the normal prosecuting authorities, in the ordinary criminal courts and this is seriously problematic. See below for a further discussion of this point.

14 Act 71 of 1988 was originally called the Harmful Business Practices Act. The title and a number of its provisions were amended in 1999 by the Harmful Business Practices Amendment Act 23 of 1999. 
may result in the entire business having to cease operating. It is a criminal offence to ignore such an order and any person convicted of an offence in terms of the Act may be liable to a fine not exceeding R200 000 or to imprisonment not exceeding five years or to both a fine and imprisonment.

There can be no doubt that this Act allows for drastic measures and is a powerful tool which can be used to alleviate at least some of the many consumer problems which are experienced in South Africa today. ${ }^{15}$ Unfortunately the Committee is under-resourced and lacks capacity to be really effective. One major drawback of the Act, especially from a consumer perspective, is that CAFCOM has no power to order redress. The role of the Committee is to advise the Minister and once an investigation is completed, a recommendation is made to the Minister who may then declare a particular practice to be illegal. It is then up to the South African police services and the prosecuting authorities to follow up any contravention of the Minister's orders. Both these entities are overloaded with other criminal matters and so consumer issues do not receive the necessary attention. There is also the attitude that consumer matters are not important. In $S$ v Pepsi-Cola (Pty) $L t d,{ }^{16}$ for example, a matter involving a marketing technique that allegedly contravened the then Gambling Act, Van den Heever $\mathrm{J}$ made the following comment:

"On reading the papers I confess to experiencing a measure of surprise that in the light of statistics for serious crime in the Western Cape, where one daily reads in the newspapers that robbery, rape and murder are rife on and from the local trains, in our parks and on our beaches, an officer in the South African Police Force can be spared to investigate a complaint of this nature."

15 The Act has come under severe criticism from the Law Review Project precisely because it does not specify exactly what constitutes an unfair business practice. In Janse Van Rensburg NO v Minister of Trade and Industry 20011 SA 29 CC it was argued that the extremely wide definition of an "harmful business practice" contained in the Act was unconstitutional because it created uncertainty. A business did not know when it planned its operations that the Committee might one day find that its practices were harmful to consumers. As the Committee reacted to complaints, a business with a substantial investment of time and money could be destroyed overnight. The Constitutional Court declined to decide this point because by the time the matter came before it, the definition of a harmful business practice had been amended and the Act dealt with unfair business practices. The court held that the issue was therefore moot. (For a discussion of this judgment, see Woker "Business Practices and the Consumer Affairs (Harmful Business Practices) Act 71 of 1988" 20012 SA Merc LJ 315). The Law Review Project continues to hold the view that the Act is unconstitutional. It seems that the DTI has heeded these criticisms because the Consumer Protection Act specifies in a fair amount of detail conduct which is prohibited. It remains to be seen whether ingenious entrepreneurs will be able to circumvent the intention of the legislation by ensuring that their conduct remains on the right side of the definitions contained in the Act. The advantage of the wide definition of an unfair business practice contained in the Consumer Affairs (Unfair Business Practices) Act means that the Committee can investigate business practices which, even though they are perfectly legal, have the effect of prejudicing consumers. The Consumer Affairs (Unfair Business Practices) Act will be repealed when the Consumer Protection Act comes into operation and the Committee will be replaced by the National Consumer Tribunal which has been established under the National Credit Act. The DTI Consumer Investigations Directorate which deals with consumer complaints will be replaced by the Consumer Commission which is presently being established in terms of the Consumer Protection Act. It was due to start performing its functions in April 2010.

1619853 SA $141(\mathrm{C})$. 
Although this case was decided over 20 years ago, the crime rate in South Africa continues to be a major problem socially, economically and politically, so it is very difficult to get the police to take consumer matters seriously. Those who do complain are often told to see their attorneys (something most consumers cannot afford to do) and when the Minister has declared something to be illegal, because of the lack of prosecutorial will on the part of the authorities, the guilty parties simply carry on regardless.

The inability of CAFCOM to do something concrete for consumers is something which they find very hard to understand. When they approach the Committee for assistance, they are in most instances expecting some form of redress, usually damages or at least a return of their purchase price. Unfortunately the Committee does not have the power to order a business to refund or compensate aggrieved consumers. During the process of negotiation and often to avoid the harmful publicity of a formal investigation, a business will refund the purchase price but there is no record of any business compensating consumers for damages which they may have suffered as a result of purchasing defective products or services.

A major innovation of the new legislation is the power of the National Consumer Tribunal to impose administrative penalties on businesses that engage in prohibited practices. ${ }^{17}$ These penalties are similar to those imposed by the Competition Tribunal and could constitute as much as 10 per cent of a business's annual turnover. ${ }^{18}$ Unfortunately the issue of consumer redress will continue to be problematic for consumers as the Tribunal does not have the power to order damages. In terms of the legislation, only a civil court has this power. An award of damages may, however, form part of a consent order which can then be confirmed by the Tribunal. This will have the effect of a High Court order. ${ }^{19}$

\section{$4 \quad$ INDUSTRY SELF-REGULATION}

Another way in which consumers can be protected is through industry selfregulation and codes of conduct. The predecessor to CAFCOM was the Business Practices Committee (BPC). ${ }^{20}$ The BPC was very supportive of self-regulation and regarded itself as complementing self-regulatory schemes which operated in particular industries. It instituted an investigation into consumer codes and the role that these codes could play in self-

17 S 151 of the National Credit Act; and s 74 (b) of the Consumer Protection Act. The Consumer Protection Act makes reference to the powers of the Tribunal as set out in the National Credit Act because the Tribunal has jurisdiction over matters governed by both Acts. A separate tribunal has not been established to deal with matters that fall under the Consumer Protection Act.

18 See Lewis "Anti-cartel Success Increases Public's Awareness of Crime" 24 February 2010 Business Report 2010 18, where David Lewis, a former chairman of the Competition Tribunal, points out that "no firm, however well resourced, enjoys paying fines of tens, and increasingly hundreds, of millions of rands".

19 See s 150 read with s 164 of the National Credit Act.

20 The name of the BPC was changed when the name of the Act was changed by the Harmful Business Practices Amendment Act. 
regulation. ${ }^{21}$ The BPC concluded that codes of conduct could make an important contribution towards preventing harmful business practices and that such codes would provide useful guidelines regarding what was regarded as acceptable conduct and what was not. The BPC devised or approved a number of industry-specific consumer codes including the following: advertising, vehicle recovery services, mail-order marketing, credit bureaus, debt recovery, franchising and time sharing.

In order for self-regulation to be truly effective there must be an industry body that has the capacity to monitor the industry and to deal with transgressors effectively. There must also be a telling sanction which will deter business people from transgressing their code. The experience of CAFCOM is that most of these codes are ignored by those involved in these industries mainly because there are very few industry-specific bodies with meaningful power to enforce them. In many instances businesses are oblivious to the fact that a code applies to their particular industry. Further, sanctions are usually meaningless and as membership of an industry body is voluntary, businesses that find themselves under investigation simply resign, leaving the industry body powerless to deal with the transgression.

An example of an effective industry body is the Advertising Standards Authority (ASA), the self-regulatory body for the advertising industry in South Africa. There are two main reasons why the ASA is successful: (1) the primary players in the industry, such as the print and broadcast media, belong to the organization; and (2) the principal sanction agreed to by the industry, namely the withholding of advertising time and space, is a very powerful sanction. $^{22}$

Most other self-regulatory bodies have not had the advantage of such an effective sanction and self-regulatory codes have not been sufficient to control abuses. For example, debt collectors used to be governed primarily by a code of conduct but, because of numerous complaints from consumers regarding harassment, debt collectors themselves lobbied government for regulation. The industry is now governed by legislation, the Debt Collectors Act, ${ }^{23}$ which establishes a Debt Collectors Council that regulates the industry. Debt collectors, excluding attorneys, are required to register with the Council before they may collect fees. It is a criminal offence to act as a debt collector without being registered. The Council can conduct hearings into the conduct of debt collectors and if found guilty of misconduct, their certificate of registration may be withdrawn. ${ }^{24}$

Although industry codes have not been that successful in South Africa, this remains a useful mechanism for advancing consumer protection. An industry body can ensure that certain standards of behaviour are maintained or at least encouraged in a particular industry, it can provide a useful starting point for consumer complaints and it can provide guidance to a regulatory

21 Business Practices Committee "Consumer Codes" R 15 GN R444 in GG 13988 of 1992-0518.

22 ASA Code of Advertising Practice ix.

23 Act 114 of 1998.

24 For further information, see http://www.debcol-council.co.za. 
body to ensure that, in protecting consumer interests, the proper functioning of the industry is not unduly impaired. Self-regulation is often more effective than government regulation because experts in the industry are able to identify genuine abuses far more readily than government officials and there is less control over legitimate activities. ${ }^{25}$ Codes of conduct are also much easier to update when problems arise and the amendment process is not hampered by the cumbersome procedures that must be followed when legislation must be amended. ${ }^{26}$ For these reasons the DTI continues to recognize the role that industry bodies can play in consumer protection and business codes will receive statutory backing in the new consumer legislation. ${ }^{27}$

\section{THE COMMON LAW}

Despite attempts by both industry and government to deal with consumer protection, in reality most consumers must rely on the general principles of the common law if they have a problem. The question then is: Does the common law provide consumers with adequate remedies? An examination of consumer complaints received by CAFCOM and the DTI reveals that most consumer complaints relate to the following:

- consent to an agreement was obtained in a improper manner - that is, the service provider used undue pressure to convince consumers to enter into the contract;

- during the negotiating process consumers were misled (they were given incorrect information, incomplete information or certain important information was withheld);

- the terms of the contract are unfair; and

- the goods purchased are defective.

\section{Defective consent}

It is a general rule of the law of contract that those who enter into legally binding agreements cannot later argue that they did not read the document, that it does not reflect their true intention or that they no longer wish to be bound by the contract. Sometimes over-zealous operators may exert sales pressure on consumers so that within a very short period of entering into the

25 Office of Fair Trading A General Duty to Trade Fairly (August 1986) 5.

26 This advantage is particularly obvious in the field of wireless technology. The technology is changing so rapidly that it is impossible for Government to keep up with the ingenious schemes of devious entrepreneurs. In August 2004 the Wireless Service Providers Association (WASPA) was formed to regulate the mobile service industry with the full support of the three network operators, Cell C, MTN and Vodacom.

27 The Consumer Protection Act provides that the Minister of Trade and Industry, acting on a recommendation from the Consumer Commission, may prescribe a code for a particular industry in regulation (s 82(2)). The Consumer Commission may decide for itself that a particular code is necessary and it may refer the matter to the Minister or persons acting within a particular industry may make a proposal to the Commission regarding the adoption of an appropriate code (s 82(3)). 
contract consumers regret their decision. Such consumers are only entitled to set the contract aside if they can show that they were "induced, through the unconscionable undermining of their independent judgment by the other, to contract when they would not otherwise have done so". ${ }^{28}$ It is not easy to set a contract aside on the basis of undue influence. This is usually only found where there is a special relationship between the parties and this relationship is abused by one of them. ${ }^{29}$

In a few limited circumstances, namely sales of $\operatorname{land}^{30}$ and credit agreements ${ }^{31}$ the legislature has introduced "cooling off" periods. ${ }^{32}$ CAFCOM has investigated a number of industries where improper pressure appears to be common to induce sales. Examples are the timeshare industry, the direct-marketing industry and the fitness industry. In the case of timeshare and direct-marketing, consumer codes were developed in conjunction with the Timeshare Institute of South Africa (TISA) and the Direct Marketing Association. CAFCOM conducted a formal investigation into the fitness industry following numerous complaints regarding lengthy long-term contracts. ${ }^{33}$ In each case a five-day cooling off period has been introduced. In all other areas a cooling off period is not required unless agreed to by the supplier.

The purpose of the Consumer Protection Act is to promote fair business practices and to protect consumers from unconscionable, unfair, unreasonable, unjust and other improper trade practices and deceptive, misleading, unfair or fraudulent conduct. It also purports to give effect to certain consumer rights. Included are the right to fair and responsible marketing ${ }^{34}$ and the right to fair and honest trading. ${ }^{35}$ These sections are

28 Sharrock Business Transactions Law 7ed (2006) 128.

29 See, eg, Preller $v$ Jordaan 19561 SA 483 (A) which deals with an elderly farmer who was induced to donate his farms to his doctor.

S 29A(1) of the Alienation of Land Act 68 of 1981.

${ }^{31} \mathrm{~S} 13$ of the Credit Agreements Act, 1980 now replaced by the National Credit Act.

32 Consumers have a number of days during which to change their minds.

33 Consumer Affairs Committee "Investigation in terms of section 8(1) (b) of the Consumer Affairs (Unfair Business Practices) Act, 71 of 1988, into a cooling off period in the fitness industry, and the selling of life long contracts, revisited" R 88 in GG 23260 of 2002-03-22. Life-time gym contracts or contracts for 10 years were common in the fitness industry. This is problematic because consumers are known to lose interest in continuing with a fitness regime fairly quickly and yet they had to continue paying for years. Other problems included long-term contracts when the period was far in excess of the lease agreement which the fitness centre had with its landlord. In addition, consumers were often led to believe that they were signing debit orders for their membership fees, which would be paid by their banks on a monthly basis. Instead, because they had handed over their credit cards, the full membership fee was deducted from the account which led to interest charges being levied on a monthly basis. This was not explained to consumers. Eg, a consumer who thought his fitness contract would cost R249 per month found instead that he was expected to pay R299 per month to his bank. On approaching his fitness centre for an explanation, he discovered that this was perfectly legitimate in terms of the contract he had signed. In circumstances where fitness centres went out of business, consumers were further prejudiced because they still owed the outstanding balance to their banks notwithstanding the fact that they no longer had a fitness centre to attend. Anecdotal evidence suggested that one fitness centre was signing 10-year contracts with consumers and debiting their credit cards the weekend before it closed down.

34 Part E. 
obviously designed to target problem areas such as marketing and advertising practices ${ }^{36}$ and the information which is provided to consumers in order to induce them to contract. It is suggested that marketers and advertisers will have to be far more careful about the extent and nature of the claims that they make and about the persuasive power they use to induce consumers to contract.

Consumers will also be entitled to cancel long-term contracts by giving notice to suppliers. ${ }^{37}$ However, suppliers will be able to charge a reasonable cancellation fee. ${ }^{38}$ The Act does not specify what is considered to be a reasonable fee but it has been suggested that if the supplier has both a monthly fee and a reduced fee for those consumers who opt for a long-term contract, the supplier may charge that amount which the consumer would have paid had he signed a monthly contract, rather than a long-term one.

\section{Deception of consumers}

During discussions with suppliers statements may be made about the terms or the nature of the contract being entered into. If these statements are later included in the final contract they are regarded as terms of the contract and a breach could lead to a breach of contract. If they do not form part of the contract they are known as representations. Representations, which turn out to be incorrect and which have induced consumers to enter into contracts are actionable in the law of delict, but it is often extremely difficult for consumers to prove that certain promises were made. This is even more difficult when consumers sign contracts which state that the written agreements constitute the entire agreement between the parties.

In addition representations are not actionable if they only constitute puffing or advertising speak. The hallmark of a puff is that nobody is expected to take it seriously; it is merely sales talk. It is a frequent cry of advertisers that statements extolling the virtues of their products are just puffs and are therefore not actionable. If a claim is a credible statement of fact, it will cease to be a puff and become a misrepresentation, but it is not always easy to decide whether statements are puffs or misrepresentations and each case has to be decided on its own merits. ${ }^{39}$ Problems relating to misleading advertising continue to plague the ASA and CAFCOM.

The failure to supply consumers with proper information regarding the true cost of credit was a major factor which led to the introduction of the National Credit Act. For example, a consumer who purchased a R5 000 lounge suite on credit with a repayment period of 24 months could end up paying

\footnotetext{
Part F.

Discussed below in 52.

S 14(2)(b)(bb) of the Consumer Protection Act.

S 14(3)(b)(i) of the Consumer Protection Act.

39 In Phame (Pty) Ltd v Paizes 1973 3 SA 397 (A) Holmes JA pointed out that sellers will always sing the praises of their wares.
} 
R32 000 for that lounge suite. ${ }^{40}$ This situation arose as a result of the 1992 Exemption Notice, ${ }^{41}$ in terms of which all loans of up to R6 $000^{42}$ to consumers were exempted from the provisions of the Usury Act. ${ }^{43}$ The only real restriction was that the loan and all finance charges had to be paid back over a period not exceeding 36 months. There was no maximum interest rate which meant that when it came to small loans, usually given to the poorest of the poor, lenders were free to charge whatever interest rate they pleased. This led to the rapid growth of the micro-lending industry and appalling exploitation of poor consumers. Consumers who could not pay cash for their goods ended up paying very high (even exorbitant) rates of interest. Consumers were also not informed about costs such as administration fees, insurance costs and delivery charges, all of which were added to the initial purchase price or loan. In many instances consumers had to enter into fresh loans to pay existing ones and were soon caught in a spiraling debt trap. ${ }^{44}$

The National Credit Act limits the amount of interest which can be charged and specifies which fees may be charged for administration and as service fees. ${ }^{45}$ In some instances, particularly for short-term unsecured loans, these costs remain very high, but the credit grantor is obliged to disclose the full cost of credit to consumers. ${ }^{46}$ Consumers must also be informed of the difference between the cash price and the total amount consumers will pay if goods are purchased on credit. It is hoped that when consumers see what the goods when purchased on credit will actually cost, they will be less inclined to purchase the goods.

\section{Unfair contract terms}

In South Africa there is legislation that deals with specific contracts or terms such as credit agreements, ${ }^{47}$ agreements for the sale of land on instalments, ${ }^{48}$ insurance warranties ${ }^{49}$ and penalty provisions. ${ }^{50}$ There is also

40 Campbell "The Cost of Credit in the Micro-Finance Industry in South Africa" (LLM thesis Rhodes University 2006) 76.

41 Notice in terms of s 15A of the Usury Act 73 of 1968, GN R3451 in GG 14498 of 1992-1231.

42 This amount was later increased to R10 000 (GN 713 in GG 20145 of 1999-06-01).

43 The main reason for introducing this exemption was to encourage credit grantors to give credit to consumers who could not provide security. These are high-risk credit agreements but the high rate of interest which could be charged meant that credit providers would be prepared to take a risk and lend money to the vast majority of the population who were excluded from the formal credit market. The explosion of the micro-lending industry and the exploitation of poor consumers was, however, unforeseen. For further discussion see DTI "Consumer Credit Law Reform: Policy Framework for Consumer Credit (August 2004)" available at http://www.thedti.gov.za/ccrdlawreview/policyjune2005.pdf (accessed 2010-0214).

44 See comments by Mynhardt $\mathrm{J}$ in Lurama Vyftien (Pty) Ltd and 49 Others $v$ The Minister of Trade and Industry (case no 22125 of 1999) (unreported TPD).

$45 \mathrm{~S} 101$ of the National Credit Act.

46 See Part B of the National Credit Act which deals with disclosure, form and effect of credit agreements.

47 The National Credit Act 34 of 2005.

48 Alienation of Land Act 68 of 1981. 
a whole host of legislation that deals with employment contracts. But there is no overarching legislation that deals with unfair contract terms and so solutions must be found in the common law.

The common law of contract is premised on the basis that there must be a meeting of the minds between two parties before there is a legally binding agreement. This suggests that the parties negotiate every term contained in the contract. In practice this is seldom the case. In most instances, consumers are presented with standard-form contracts, sometimes several pages long with small print, and asked to sign. ${ }^{51}$ Contracts, often signed without consumers reading or understanding the legal nature of the document, tend to contain terms that favour the drafting party. Consumers who sign standard-form contracts have always found it extremely difficult to prove that they are not bound by these terms. The courts have held that people who sign documents are agreeing to whatever words appear above their signatures and it is only in instances where it can be proved that the signatory was misled by the supplier that the offending terms will not apply. ${ }^{52}$

Even when consumers are not asked to sign documents, unfair terms may still be part of their contracts. It is common practice for suppliers to put up notices or to hand out tickets that contain such terms. It is generally accepted that it is impossible to inform every person about the terms on which a supplier is prepared to contract. Therefore, provided the terms are in contractual form, ${ }^{53}$ are prior to or contemporaneous with the contract ${ }^{54}$ and sufficient notification of them has been given, ${ }^{55}$ the courts will find that they are part of the contract. However, the rule goes even further than this: even if consumers did not see the notice or did not read what it contained they will be bound to a contract containing these terms as long as the supplier did what was reasonably necessary to bring such terms to their notice. ${ }^{56}$ Some decisions appear to support the proposition that the onus is on consumers to seek out the terms of the contract. ${ }^{57}$ Even though the exact terms are not presented to the consumer at the time of entering into the contract, the mere fact that there is a term at the bottom of the document or a large notice

49 S 59 of the Long Term Insurance Act 52 of 1998; and s 53 of the Short Term Insurance Act 53 of 1998.

50 Conventional Penalties Act 15 of 1962.

51 See comments by Sachs J in Barkhuizen v Napier 20071 SA 323 CC 356-381.

52 The principle that applies is caveat subscriptor or "let the signer beware". See, eg, Afrox Healthcare Bpk v Strydom 20026 SA 21 (SCA); and KPMG Chartered Accountantss (SA) $v$ Securefin Ltd 20094 SA 399 SCA. In Freddy Hirsch Group (Pty) Ltd v Chickenland (Pty) Ltd 20101 SA 8 GSJ the court stated that it is "settled law that generally a person who signs a contractual document thereby signifies his assent to the contents of the document" (17D). In Barkhuizen $v$ Napier supra Sachs $\mathrm{J}$ criticised judges for not being prepared to overturn principles of the common law in order to dispense justice (368G) and argued that their "vision has become so clouded by anachronistic doctrine as to prevent them from seeing objective reality" (369C-D).

53 CSAR v McLaren 1903 TS 727.

54 Olley v Marlborough Court (1949) 1 KB 532 (CA).

55 Bok Clothing Manufacturers v Lady Land 19822 SA 565 (C).

56 Durban's Water Wonderland (Pty) Ltd v Botha 19991 SA 982 (SCA).

57 See Woker "Caveat Subscriptor - How Careful are We Expected to Be" 20031 SA Merc LJ 109-116. 
behind the desk referring very simply to "usual terms and conditions" without these being spelt out may be sufficient to ensure that an exemption clause (or other terms limiting consumer rights) is part of the agreement. ${ }^{58}$

The courts will condemn contracts that are so clearly one-sided or oppressive that they are contrary to public policy, ${ }^{59}$ but the Supreme Court of Appeal has stated that the courts' power to interfere with contracts in this manner should be "exercised sparingly and only in cases in which the impropriety of the transaction and the element of public harm are manifest". 60 The Constitutional Court, in Barkhuizen v Napier, has stated that even if a clause is a reasonable one the court may refuse to uphold it in the light of the specific circumstances of the case ${ }^{61}$ Factors which the court may take into consideration include the unequal bargaining position of the parties. This decision will have important implications for the protection of consumers in the future nevertheless the Constitutional Court confirmed that public policy in general does require that a party should comply with a contractual obligation that has been freely and voluntarily undertaken. ${ }^{62}$ The onus will therefore be on consumers to demonstrate that it would be against public policy to enforce a clause in their particular circumstances.

The question of unfair contract terms has been a matter of concern for years. In 1996 the South African Law Commission published a report recommending the introduction of legislation that would allow the courts to review unfair contract terms. ${ }^{63}$ Both the National Credit Act and the Consumer Protection Act have substantial sections dealing with unlawful agreements and provisions. ${ }^{64}$ The introduction of this legislation will alter the way in which courts approach contractual disputes fundamentally.

\section{Liability for defective goods}

The extent of a consumer's remedy for defective goods in South Africa depends first of all on the seriousness of the defect. To afford any relief the defect must be such as to hinder or prevent the use of the goods substantially. Trifling defects are not actionable. In circumstances where there is no breach of an express or implied warranty, ${ }^{65}$ suppliers have not acted fraudulently nor did they manufacture the goods or profess to be expert sellers, in other words the goods were purchased from the local

58 Home Fires Transvaal CC v Van Wyk 20022 SA 375 (WLD); Africa Solar (Pty) Ltd v Divwatt (Pty) Ltd 20024 SA 681 (SCA); and Cape Group Construction (Pty) Ltd t/a Forbes Waterproofing $v$ Government of the United Kingdom 20035 SA 182 (SCA).

59 See, eg, Sasfin v Beukes 19891 SA 1 (A); and Baart v Malan 19902 SA 862 (E).

60 Botha v Finanscredit 19893 SA 773(A) 783.

61 Per Ngcobo J 341B.

62 341B-C.

63 South African Law Commission Discussion Paper 65 "Unreasonable Stipulations in Contracts and the Rectification of Contracts" (1998).

64 S 89 and S 90 of the National Credit Act 38 of 2005 and Part G of the Consumer Protection Act 68 of 2008.

65 The supplier may, eg, guarantee that the goods are fit for a particular purpose, alternatively there is an implied warranty that the goods are fit for the purpose for which they have been purchased. 
supermarket, consumers are only entitled to very limited remedies. ${ }^{66}$ They can obtain a reduction in the purchase price or they can reclaim their money, but these limited remedies do not include damages for any consequential loss. This is problematic because in many instances the purchase price is negligible when compared to the damages that have been suffered. Consumers who become seriously ill after eating tins of contaminated fish purchased from a local supermarket are not interested in reclaiming the purchase price. They are really concerned with medical bills, loss of income and perhaps even permanent disability. There may be an action in delict against the manufacturer of the product but consumers are required to show that the manufacturer acted negligently. This is even more difficult when the product is imported. Other jurisdictions have adopted legislation to hold those who supply defective products strictly liable for any defects. ${ }^{67}$

Problems experienced by consumers in this regard were illustrated in the case of in Wagener $v$ Pharmacare Ltd; Cuttings $v$ Pharmacare $L t d{ }^{68}$ In this matter a hospital patient underwent shoulder surgery. During the operation she received a local anaesthetic and after the operation, she was left with a paralysed right arm. She brought an action for damages for personal injuries against the manufacturer alleging that her injuries were caused by the anaesthetic. The main claim was based on the allegation that, contrary to its duty as manufacturer, the anaesthetic administered was unsafe for use as a local anaesthetic because it had resulted in paralysis. The essential inquiry was whether the manufacturer was strictly liable because no negligence was alleged (which in any event would have been very difficult to prove).

A study of the appeal judgment suggests that the appellants resorted to all the arguments that have, over time, been advocated by the various and numerous academics in South Africa and elsewhere that have called for strict liability. The appellants took this a step further by relying on the Constitution, ${ }^{69}$ arguing that their common-law remedy was inadequate to protect their constitutional right to bodily integrity. ${ }^{70}$ They contended that in terms of the Constitution, the court was obliged to develop the common law and to "fashion a remedy" that did achieve the requisite protection. They asked the court to make a policy decision in order to cater for what was "an obvious weakness in an injured consumer's legal armoury". This, the Supreme Court of Appeal declined to do. The court found that in all industrialized nations where there is strict liability, this has been imposed by statute and concluded that, if strict liability was to be imposed then it is the legislature that must do it. So, this is what the legislature intends to do. ${ }^{71}$

66 These are known as the aedilitian remedies. These are special remedies that have evolved from the Aediles' Edict of Roman Law and are enforced by the actio redhibitoria for rescission of the contract or the actio quanti minoris for a reduction in the purchase price.

67 See, eg, the English Consumer Protection Act 1987 which implemented the European Community Directive on Liability for Defective Products 1985 (85/374/EEC); and generally McQuoid Mason "Consumers and Product Liability" 1996 Consumer Law in South Africa 64.

6820034 SA 285 (SCA).

69 The Constitution of the Republic of South Africa, 1996.

292B-C.

$71 \mathrm{~S} 61$ of the Consumer Protection Act 68 of 2008. 


\section{CONCLUDING REMARKS}

Consumer law in South Africa is (for the most part) fragmented and outdated and many of the consumer principles which are accepted internationally are denied to South African consumers, such as the right to fair contract terms and the right to transparent marketing and advertising practices. It is my submission that the argument which says that legislation is unnecessary and will simply further burden the South African economy ignores reality. In consumer transactions unfair practices are widespread. The existing law is still founded on the principles such as caveat emptor - meaning "let the buyer beware". That principle may have been appropriate for transactions conducted in village markets where people often knew the manufacturer of product and had ample opportunity to examine the simple products they were purchasing. Now the marketing of goods and services is highly sophisticated and untrained consumers cannot hope to compete with entrepreneurs who are able to persuade them to buy goods or services on terms and conditions which are designed to protect the interests of suppliers. ${ }^{72}$ Even educated consumers face difficulties in today's sophisticated modern world where goods come in sealed packages or consist of complicated electronic devices. ${ }^{73}$ In some instances consumers do not even know that they are being affected adversely by the products that they buy, for example food additives and drugs. ${ }^{74}$ Consumers must rely on the information which they receive from suppliers. Added to this is the problem that business and consumers tend to be in an unequal bargaining position, so consumers who confront businesses with problems find that they are simply ignored. Consumers do not have the financial resources to fight for their rights. Litigation is notoriously expensive and because of the relatively small sums that are often involved, it does not make financial sense for consumers to take the matter to court. In an ideal world business would realize that consumers are their most important asset but the world is not ideal, so unfortunately public control is frequently the only way that

72 Words of Senator John Murphy, the then Australian Attorney-General when he introduced the Trade Practices Bill of the Commonwealth of Australia in the Senate. This bill resulted in the Trade Practices Act 1974 which is concerned with restrictive trade practices and consumer protection. The section that deals with consumer protection (Part V) is aimed at eliminating unfair competition in business as well as improving the position of consumers.

73 The recent recall by Toyota of 8.5 million motor vehicles worldwide has highlighted this problem. See "Toyota Chief Comes under Heavy US Fire" 25 February 2010 Daily News 4. Federal safety officials have received reports linking 34 deaths in the United States of America to safety defects in Toyota cars and trucks over the past decade.

74 In Freddy Hirsch Group (Pty) Ltd v Chickenland (Pty (Ltd) supra, Nando's, a chain of quickservice chicken restaurants, refused to pay for spices which it had purchased from its supplier because the spices were contaminated with Sudan Red 1, an artificial colourant that is a banned substance and unfit for human consumption. Nando's counter-claimed for the damages it had suffered as a result of being forced to withdraw its products from the market. Another example is the melamine scandal which emerged in China. Thousands of babies became ill after consuming baby milk laced with melamine, another product unfit for human consumption. The melamine was deliberately added to the milk powder to boost its protein content and to fool inspectors (see National Consumer Forum "Putting Consumer Issues on the Agenda" (2008) www.ncf.org.za/docs/publications/consumerfair/voll16/part1. pdf (accessed 2010-02-25). 
consumers will be protected. ${ }^{75}$ There is a need for carefully structured checks, balances and safety nets to make the free market work in a way that considers both the interests of business and consumers ${ }^{76}$ even though this may lead to increased costs and the economy may be less efficient. This is preferable to allowing the exploitation of consumers to go unchecked and is even more important now because, since 1994, the South African economy has opened up to international trade. A South African market without significant consumer protection measures, coupled with a proper regulatory framework, could become a dumping ground for unsafe and substandard products and South Africa's vulnerable consumers will continue to be exploited with impunity.

The next question to be discussed is whether the National Credit Act and the Consumer Protection Act will actually achieve their aims of providing consumers with appropriate protection in today's highly sophisticated market. This is a topic for another day. Suffice to say that only time will tell whether the legislation will achieve its lofty aims. However, many have acknowledged that the introduction of the National Credit Act has shielded South Africa from the worst excesses of the global recession. It is hoped that the Consumer Protection Act will likewise encourage South African entrepreneurs to change the way in which they do business.

75 Cranston 3

76 Harvey and Parry The Law of Consumer Protection and Fair Trading (1994) 18. 